\title{
Designing a Knowledge Review, Based on Connectivism of Cloud Computing for Developing Critical Thinking
}

\author{
Nawin Kongrugsa, Prachyanun Nilsook, and Panita Wannapiroon
}

\begin{abstract}
The objectives of the research were to analyze and synthesize the learning theories and concepts and to design a knowledge review with steps based on connectivism on cloud computing. The qualitative research was to analyze and synthesize the learning theories and learning procedures of the connectivism concept, with a knowledge review concept that was based on the leaning support activities of students with low grades. The knowledge review that was based on connectivism was a learning process to develop knowledge. The research results revealed that there were five steps in the knowledge review process, including: 1) determining the conditions for learning; 2) knowledge finding; 3) knowledge connecting; 4) knowledge discussions and answering a question; 5) knowledge presentation. Finally, the knowledge review, which was based on connectivism, was the learning support activities for students on cloud computing, being applied both inside and outside the classroom.
\end{abstract}

Index Terms-Knowledge review, connectivism, cloud computing, critical thinking.

\section{INTRODUCTION}

The Thailand Information and Communication Technology (ICT) Policy Framework (2011-2020) or ICT 2020 [1] for short, was carried out under the "Smart Thailand 2020 " vision, in which, "ICT" was a key driving force for the Thai people to achieve knowledge and wisdom, as well as leading the society towards equality and a sustainable economy. This smart form of development, using a knowledge and wisdom-based economy and society, will enable its people to have equal opportunities to take part in the development process with an objective to bring balanced and sustainable growth to Thailand. Further, according to the Educational Strategy no. 1 by the Ministry of Education [2], Thailand has continuously encouraged an application of information and communication technologies (ICT) in teaching and learning approaches, in order to ensure an effective education. It aims to create the manpower of the country by enhancing learning that focuses mainly within a technological setting. As it is increasingly used today, the "system based on connectivism on cloud computing" was created to agree with the educational strategy no. 1 by the Ministry of Education, which will become a channel to continue the development of teaching and learning in Thailand.

We used classroom action research to find learning outcomes and learning behavior on a computer course. Doubt

Manuscript received November 10, 2014; revised January 4, 2015

The authors are with the King Mongkut's University of Technology North Bangkok, Bangkok, Thailand (e-mail: nawin30@hotmail.com, pruchyanunn@kmutnb.ac.th, panitaw@kmutnb.ac.th). that the tested was as follows: students took an examination after the teacher taught them for four hours. The research found that eighty percent of the students failed the examination. The causes for failing the exam were lack of interest in the earliest stage of the learning activity and indifferent learning. Moreover, forty percent of students had many other causes for failure, including slow interpretation, slow thinking, and using social media and social networks via smart phones and computers. The eighty percent student failure rate was due to problems in the education process. The researcher recommended that the learning procedures, including the learning process, thinking process, and synthesis of the knowledge review process be developed by creating learning for the students and the development of quality education [3].

A large amount of information, diverse learning tools, and secure connection to the Internet allow for learning over the course of a lifetime [4]. In 2004, George Siemens and Stephen Downes developed a theory called connectivism, which was defined as "A learning theory for the digital age". This hypothesis states that a "node" refers to any information that exists in any form: messages, symbols, images, and sounds. Each "node" can link to one another with its "connection". George Siemens's conception was that learning occurs through seeing a network with nodes and connections, knowing how they are connected, and interpreting the patterns of their connections to develop knowledge. While connectivism is being introduced from an advanced Internet technology that changes rapidly the whole time, today's learning styles have been altered, unlike the past. Connectivism is the digital age's learning theory, based on these principles: 1) learning and knowledge rests in the diversity of opinions; 2) learning is a process of connecting specialized nodes or information sources; 3 ) learning may reside in non-human appliances; 4) the capacity to know more is more critical than what is currently known; 5) nurturing and maintaining connections is needed to facilitate continual learning; 6) the ability to see connections between fields, ideas, and concepts is a core skill; 7) currency (accurate, up-to-date knowledge) is the intent of all connectivist learning activities; 8) decision-making is, itself, a learning process. Choosing what to learn and the meaning of incoming information is seen through the lens of a shifting reality [5]. While there is a right answer now, it may be wrong tomorrow, due to alterations in the information climate affecting the decision. Thus, connectivism is considerably compatible with the digital age.

From the problems discovered, the researcher intended to analyze and synthesize learning theories and concepts and to design knowledge review steps based on connectivism in cloud computing and blended knowledge between learning 
processes, knowledge review processes, and the connectivism concept to design the knowledge review system, based on connectivism in cloud computing.

\section{OBJECTIVES OF THE STUDY}

The objectives of the research were to analyze and synthesize the learning theories and concepts and design knowledge review steps based on connectivism in cloud computing.

\section{RESEARCH PROCEDURE}

The research methodology chosen was qualitative research, which consisted of three steps. The first step was the analysis and synthesis of learning theories, including pre-20 ${ }^{\text {th }}$ Century learning theories, 20th Century learning theories, new age learning theories, and 21st Century student skills and learning outcomes to design the learning process. The second step was the synthesis of the learning method, by applying the knowledge review procedure based on designing a concept of elementary set theory. The elementary set theory is a branch of mathematical logic that studies sets, which are collections of objects. Although any type of object can be collected into a set, set theory is applied most often to objects that are relevant to mathematics. The third step was blended knowledge between the learning process, knowledge review process, and connectivism concept to design the knowledge review system based on connectivism in cloud computing. The data presentation included a description and flowchart of the knowledge review process.

\section{RESULTS}

Results of the research study are presented as follows:

Part 1 results: There have been many studies, analyses, and synthesis learning theories over the years, including pre- $20^{\text {th }}$ Century learning theories, $20^{\text {th }}$ Century learning theories, new age learning theories, and $21^{\text {st }}$ Century student skills and learning outcomes [6], which have enabled the design of the learning process shown in Fig. 1.

\begin{tabular}{|c|c|c|c|}
\hline $\begin{array}{l}\text { Pre- 20 } 0^{\text {th }} \text { Century } \\
\text { learning theories } \\
\text { - Mental } \\
\text { Discipline } \\
\text { - Natural } \\
\text { Unfoldment } \\
\text { - Apperception }\end{array}$ & $\begin{array}{l}20^{\text {th }} \text { Century } \\
\text { learning } \\
\text { theories } \\
\text { - Behaviourism } \\
\text { - Cognitivism } \\
\text { - Humanism } \\
\text { - Eclecticism }\end{array}$ & $\begin{array}{l}\text { New age learning } \\
\text { theories } \\
\text { - Multiple } \\
\text { Intelligences } \\
\text { - Constructivism } \\
\text { - Constructionism } \\
\text { - Cooperative or } \\
\text { Collaborative } \\
\text { Learning }\end{array}$ & $\begin{array}{l}21^{\text {st }} \text { Century } \\
\text { student } \\
\text { skills and } \\
\text { learning } \\
\text { outcomes }\end{array}$ \\
\hline \multicolumn{4}{|l|}{$\begin{array}{l}\text { 2. Knowledge find } \\
\text { 3. All knowledge } \\
\text { 4. Conclusion fron }\end{array}$} \\
\hline
\end{tabular}

Fig. 1. Analysis and synthesis learning theories to design learning process.

Part 2 results: Study principle and theory of critical thinking: the critical thinking theory was the thinking process of Watson and Glaser [7], which consisted of five components and eight subcomponents. The first component consisted of three subcomponents, including attitude, knowledge, and skills. The 'attitude' was finding problems, including the ability to find problems and persistently putting effort in a task. The 'knowledge' was the ability to summarize, which was based on principle and logic. The 'skill' was applying that knowledge and attitude in problem solving.

The second component was thinking abilities, which consisted of five subcomponents, including analyzing data, acceptation that was assumption, inference discussing problems, and findings to add data, interpretation of data and the ability to manage data and evaluation agreement. The critical thinking process of Ennis [8] consisted of two essential elements, including the ability of the author in critical thinking and skills.

Part 3 results: A synthesis of the knowledge review steps, based on the principles and theories from parts 1 and 2, are illustrated in Table I.

TABLE I: SYNTHESIS OF KNOWLEDGE REVIEW STEPS, BASE ON PRINCIPLES AND THEORIES

\begin{tabular}{lccc}
\hline \hline \multicolumn{1}{c}{ Process } & $\begin{array}{c}\text { Learning } \\
\text { process }\end{array}$ & $\begin{array}{c}\text { Connectivism } \\
\text { (Siemens, 2004) }\end{array}$ & $\begin{array}{c}\text { Critical Thinking } \\
\text { (Watson and } \\
\text { Glaser, 1964) and } \\
\text { (Ennis, 1987) }\end{array}$ \\
\hline $\begin{array}{l}\text { 1. Determining } \\
\text { the conditions of } \\
\text { learning }\end{array}$ & $\checkmark$ & $\checkmark$ \\
\hline $\begin{array}{l}\text { 2. Knowledge } \\
\text { finding }\end{array}$ & $\checkmark$ & $\checkmark$ & $\checkmark$ \\
\hline $\begin{array}{l}\text { 3. Knowledge } \\
\text { connecting }\end{array}$ & $\checkmark$ & $\checkmark$ & $\checkmark$ \\
\hline $\begin{array}{l}\text { 4. Knowledge } \\
\text { discussions and } \\
\text { answering a } \\
\text { question }\end{array}$ & $\checkmark$ & $\checkmark$ & $\checkmark$ \\
\hline $\begin{array}{l}\text { 5. Knowledge } \\
\text { presentation }\end{array}$ & $\checkmark$ & & $\checkmark$ \\
\hline \hline
\end{tabular}

Table I shows the synthesis of knowledge review steps, based on the principles and theories presented in Fig. 2.

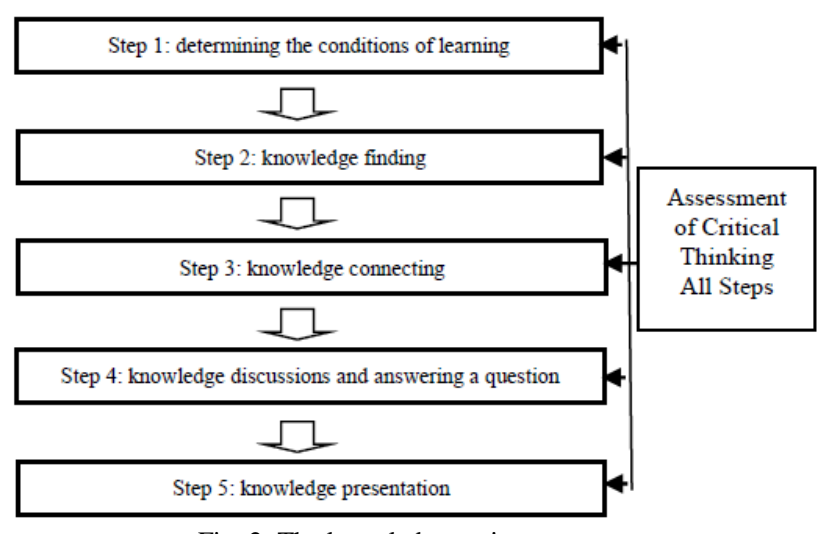

Fig. 2. The knowledge review process.

Step 1: Determining the conditions of learning

The activity learning procedure, agreement and defining issues for the knowledge review were defined. The conductor in the classroom defined the topic issues which were appropriate for the students for the knowledge review, based on connectivism in cloud computing.

Step 2: Knowledge finding

These were knowledge review activities that the member needed to discover information from data resources. In the knowledge-finding step, the students found knowledge, which could be in the form of text, pictures, animation, and 
multimedia on social networks online via smart phones, tablets, and computers. This step had the protection of copy data in the knowledge finding process, so that the member did not share data with the group activity show in Fig. 3.

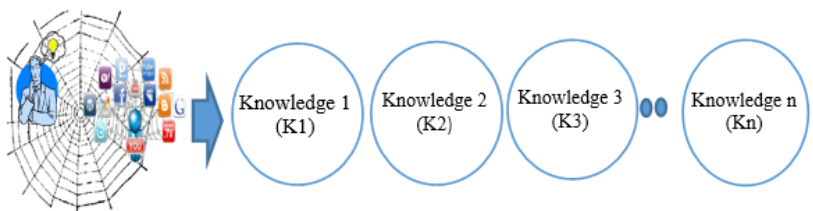

Fig. 3. Knowledge finding in the members' group activity.

\section{Step 3: Knowledge connecting}

The members' group activity compiled their findings to present it to all members of the group and connect the knowledge. This connected blended knowledge, prior knowledge and new knowledge, based on the connectivism concept, which was the intersection of key words and compilation of new knowledge. Finally, the output was individual knowledge. The members' group activity can look at the final knowledge when all members took the knowledge summary show in Fig. 4.

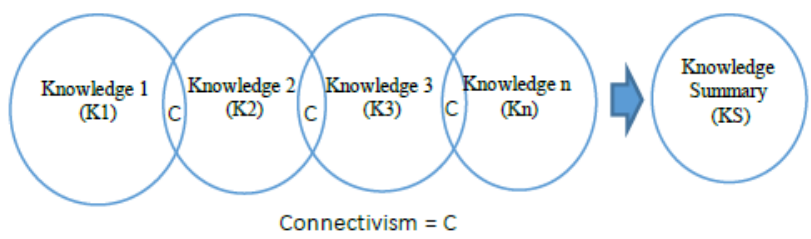

Fig. 4. Knowledge connecting of the members' group activity.

Step 4: Knowledge discussions and answering a question The members' group activity showed the knowledge findings to all. The members had discussions and answered a question regarding the knowledge summary show in Fig. 5.

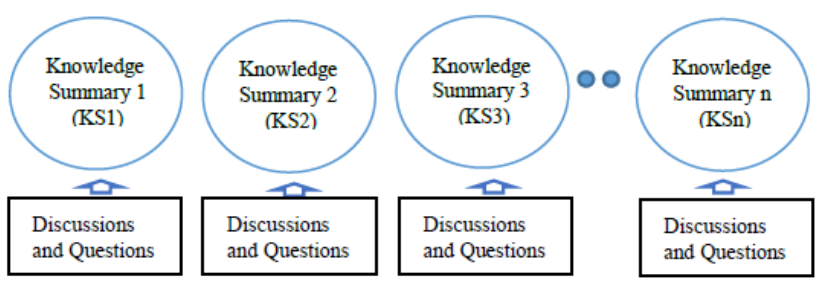

Fig. 5. Knowledge discussions and answering a question in the members' group activity.

Step 5: Knowledge presentation

The members' group activity concluded with a knowledge summary, including knowledge issues and arguments, which formed the reducible knowledge. Finally, the reducible knowledge was presented in the knowledge review article show in Fig. 6.

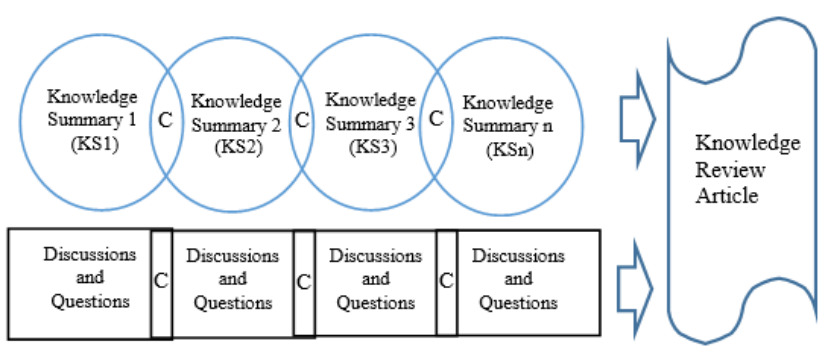

Fig. 6. Knowledge presentation in the knowledge review article.

Part 4 results: There was blended knowledge between the learning process, knowledge review process, and connectivism concept, to design the knowledge review system based on connectivism on Cloud Computing. This system development relied on the System Development Life Cycle (SDLC), which included seven stages in total [9] and the system design of the knowledge review system, based on connectivism [KRSC3] was the designing of a system through the use of Software as a Service on Cloud Computing, as presented in Fig. 7.

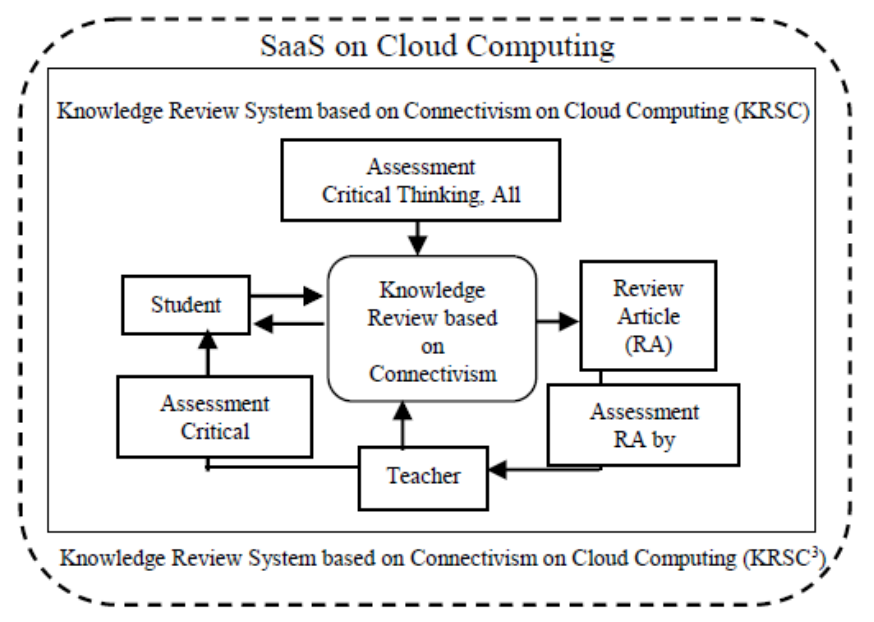

Fig. 7. Process of the knowledge review system, based on connectivism on cloud computing $\left(\mathrm{KRSC}^{3}\right)$.

\section{DISCUSSIONS}

Finally, the purposes of the research study were to solve the problems of students, improve the learning process and knowledge sharing, and to develop leaning support activities for students with low grades. The knowledge review system, based on connectivism on cloud computing, was the learning support activity model used to develop in the cloud-computing environment. The designing principle had protection copy data in the knowledge finding process, so that the member did not share data to the group activity. The members' group activity could share data in knowledge connecting and knowledge discussions and could answer a question. This step can be used to classify student groups, which had good or poor grades. The highlighted knowledge review activity shared knowledge to all members of the group, [10] bringing the core concepts detected by the analysis to define principles and elements. The result agreed with the study by Shawnz Neo and Jun Megata [11], stating that m-learning in a trial shuttle has encouraged out-of-school learning. Learners can take part in the activities out of class and reply to the situation as real-time. Meanwhile, an instructor can also receive information from them as real-time. [12] Designed a new learning innovation-by-innovation media to deliver an awareness of creative ICT use among the young.

\section{CONCLUSION}

Finally, the knowledge review process consisted of five steps, including: 1) determining the conditions of learning; 2) knowledge finding; 3) knowledge connecting; 4) knowledge discussions and answering a question, and 5) knowledge 
presentation. The knowledge review was based on connectivism in the learning support activities for students on cloud computing, being applied both inside and outside the classroom.

\section{ACKNOWLEDGMENTS}

The researchers would like to thank the Vocational Education Technology Research Center and Innovation and Technology Research Center at the Science and Technology Research Institute, King Mongkut's University of Technology, North Bangkok, which supported this research. Special thanks to the Faculty of Science and Technology, Muban Chombueng Rajabhat University, which supported the tools and location for the research.

\section{REFERENCES}

[1] Thailand Information and Communication Technology Policy Framework (2011-2020), Ministry of Information and Communication Technology, Bangkok, Thailand, 2011.

[2] Master Plan for the Information and Communications Technology (2014-2016), Ministry of Education, Bangkok, Thailand, 2014.

[3] National Qualifications Framework (Thailand NQF), Office of the Education Council Ministry of Education, Bangkok, Thailand, 2013.

[4] N. Jeerungsuwan, Instructional Design and Assessment, $2^{\text {nd }}$ ed., Kmuutnb, Thailand: Book Center, 2012, pp. 18-21.

[5] G. Siemens. (December 2004). Connectivism: A Learning Theory for the Digital Age. [Online]. pp. 1-59. Available: http://www.elearnspace.org/Articles/connectivism.htm

[6] T. Khemmanee, Science of Teaching, $15^{\text {th }}$ ed., CU, Thailand.: Book Center, 2012. pp. 46-98.

[7] G. Watson and E. M. Glaser, Watson-Glaser Critical Thinking Appraisal Harcourt, New York, U.S.A.: Pearson Education, Inc, 1964, pp. 3-45.

[8] R. H. Ennis, A Logical Basic for Measuring Critical Thinking Skills, Education Leadership, 1985, pp. 45-48.

[9] T. Nitiwadee, "Effectiveness evaluation of information retrieval," Library Journal, vol. 45, no. 3, p. 44, July-September 2001.

[10] P. Nilsook, N. Utakrit, and J. Clayden, "Imagineering in education: A framework to enhance students' learning performance and creativity in thinking," Educational Technology, vol. 54, no. 1, pp. 14-20, January-February 2014.

[11] S. Neo and J. Magata, "Location-based mobile learning in Singapore schools," in Proc. International e-Learning Conference IEC, pp. 49-53, 2012.

[12] C. Kemwimuttiwong, "Innovation of knowledge-based hyper-multimedia to promote a culture of using ICT creatively for adolescents," in Proc. Smart Innovation in Education \& Lifelong Learning TEC, pp. 38-41, 2012.

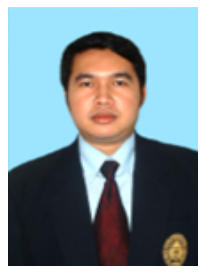

Nawin Kongrugsa is studying for the doctor of philosophy in information and communication technology for education, Faculty of Technical Education, King Mongkut's University of Technology, North Bangkok, Thailand. He obtained the bachelor's degree in computer science from the Faculty of Science and Technology, Muban Chombueng Rajabhat Institute, Ratchaburi, Thailand in 1999, and received a master's degree in telecommunication and computer networks from the Faculty of Engineering from the College of Engineering, Rungsit University, Bangkok, Thailand. He is currently a full-time lecturer at the Department of Computer Science, Faculty of Science and Technology, Muban Chombueng Rajabhat University, Ratachaburi, Thailand.

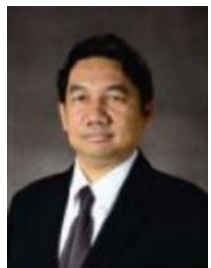

Prachyanun Nilsook is an associate professor at the division of information and communication technology for education, Faculty of Technical Education, King Mongkut's University of Technology, North Bangkok (Kmutnb), Thailand. He received the B.Ed. degree in audio-visual education from the Faculty of Education, Ramkhamhang University, Thailand in 1989. He obtained his M.Ed. degree in educational technology from the Faculty of Education, Srinakarinwirot University, Thailand in 1995, and received a Ph.D. degree in educational communications and technology from Faculty of Education, Chulalongkorn University in 2001. He currently works in the field of information and communication technology in education. He has experience in many positions, such as the dean of the Faculty of Technical Education, Samutsongkhram Technical Collage, the dean of the Faculty of Information and Communication Technology, Samutsongkhram Technical Collage, and the director of the Vocational Education Technology Research Center. He received a National Teachers Award of the Year in Higher Education in 2004 from the National Teacher Council, Ministry of Education, Thailand. He is a member of Professional Societies in the Association for Educational Technology of Thailand (AETT).

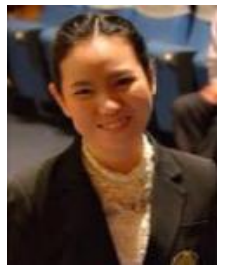

Panita Wannapiroon is an assistant professor at the division of information and communication technology for education, Faculty of Technical Education, King Mongkut's University of Technology, North Bangkok (Kmutnb), Thailand. She received the B.Ed. degree in educational technology from the Faculty of Education, Burapha University, Thailand in 1999. She obtained her M.Ed. degree in educational technology from the Faculty of Education, Burapha University, Thailand in 2002, and received a $\mathrm{Ph} . \mathrm{D}$. degree in educational communications and technology from the Faculty of Education, Chulalongkorn University in 2008. Presently, she works in the field of information and communication technology in education. She has experience in many positions, such as an assistant director of the Online Learning Research Center, an assistant director of the Vocational Education Technology Research Center, and an assistant director of Information and Communication Technology in the Education Research Center. She received the Burapha University Thesis Award 2002, Burapha University, Thailand. She is a member of Professional Societies in the Apec Learning Community Builders, Thailand (ALCoB), and Association for Educational Technology of Thailand (AETT). 